\title{
ANALYSIS OF DETERMINATION FOR FAIR REPLACEMENT VALUE OF LAND ACQUISITION FOR PUBLIC INTEREST: A CASE STUDY IN KACANG BUTOR VILLAGE
}

\author{
Yanuarti K.*, Sukoharsono E.G., Achsin M. \\ Faculty of Economics and Business, University of Brawijaya, Indonesia \\ *E-mail: niakoe68@yahoo.com
}

\begin{abstract}
Land acquisition has many obstacles due to the refusal of the landowners that will be acquired, this is because landowners disagree with the value of compensation provided by the government. This research aims to provide a solution for the problem so that the implementation of land acquisition can be done and the landowners can receive the compensation given. In this research used analytical descriptive method: to determine Fair Reimbursement Value, researcher combined the value of physical loss and the value of nonphysical loss resulting from the calculation of premium, income tax, officials of the land deed, the interest of the waiting period, and other losses. The result of interview with landowners shows that they tend to choose the calculation from fair reimbursement value that calculated by researcher.
\end{abstract}

\section{KEY WORDS}

Land acquisition, development, public interest, fair replacement value, physical loss, nonphysical loss.

Necessity of land for development in Indonesia is soaring, either as residence, place for doing business (Mulyanti, 2013), or infrastructure for public interest. Fratmawati (2006) assert that the need for land is a matter that concerned the most fundamental right of people. Therefore personal interest on land can be sacrificed for public interest. Development for public interest is aimed to embody just, prosperous, and welfare of society. It can be manifested as facilities and infrastructure that society need. In implementing the development of facilities and infrastructure, the obstacles often faced are the limited availability of land. Public facilities and infrastructure development can be accomplished if it is supported by the availability of land that the provision is made through the process of land acquisition.

To accommodate fair and democratic land acquisition process of development for public interest, owners of the land are given feasible and fair compensation. There is a regulations that issued to accommodate fair and democratic enforcement of land procurement i.e. Law No. 2 of 2012 regarding Land Procurement for Development for Public Interest. Home Affairs (Regulation of Minister of Home Affairs) No. 15 of 1975, regarding Provisions Concerning Procedure of Land Acquisition; Presidential Decree No. 55 of 1993 regarding Land Procurement for the Implementation of Public Interest Development; Presidential Regulation No. 36 of 2005 which was subsequently changed to Presidential Decree No. 65 of 2006 regarding Land Procurement for the Public Interest Development are the others regulations regarding land acquisition of development for public interest.

Legislation is issued in hope of mitigating every problem occurred in land procurement process. Implementation of land procurement is often constrained by discrepancy between the value of compensation offered by government and value of compensation expected by the landowner affected by the exemption. The above regulations basically provide solutions for land acquisition of development for public interest, but sometimes there are still problems that cause obstruction of land procurement for development for public interest. Discrepancy in expected value of compensation occurs likely due to information asymmetry between government and landowners.

Government maybe has more awareness regarding the exact amount of compensation for land acquisition but landowners don't. Information asymmetry characterizes almost every 
types of assets (Adler, Stringer, and Yap, 2016) land particularly. Land is one of the most essential assets because of its characteristic that prone to be subject of compulsory acquisition for public interest (Ogedengbe, 2007) especially in developing countries (Odudu, 2017) such as Indonesia. Land that acquired by government will be used to renew and to develop new infrastructure which are often defined as public purposes (Mangioni, 2010). Adam (2015) explicate that soaring demand for land is due to growing number of people causing increased demand for housing and residential development. In this case, government is required to provide what society needs (Alemu, 2013).

In determining the amount of compensation for land acquisition, government is constrained by several things, such as information asymmetry. Alemu (2013) generally explains that there are three problems that always occur in land acquisition process, namely legal, technical and financial. Furthermore Alemu (2013) in his research mentioned that the greatest reason for landowners objections to land acquisition (especially in Ethiopia) is inadequacy of compensation given by government. It shows that the main problem in land acquisition especially in developing countries in is inadequacy felt by landowners. Existence of external appraisers is an essential aspect to mitigate information asymmetry (Muller III and Riedl, 2002) and provides an objective assessment of compensation from a third party point of view.

A significant amount of research about land acquisition or expropriation for public interest has been done before. Although some previous studies have been done in developed countries but majority of them have been done in developing countries, such as Nigeria (Babatunde, Adeniyi, and Awodele, 2017; Odudu, 2017; Ogedengbe, 2007; Opawole and Jagboro, 2016a; Opawole and Jagboro, 2016b), Ethiopia (Adam, 2015; Alemu, 2013), Pakistan (Noor, Khalfan, and Maqsood, 2013), Estonia (Dickinson, 2010), Malaysia (Omar and Ismail, 2009) and Australia (Mangioni, 2010; Newell, Chan, and Goodridge, 2011). Similar studies have also been done in Indonesia such as Fratmawati (2006) and Mulyanti (2013) studies. Both of previous studies focused on legal aspect regarding land acquisition for public interest, but our research is focused on financial aspect that is the most significant aspect arousing detention in development of infrastructure and facilities for public interest.

This research is conducted in Indonesia which in fact is a developing country with a very high population that continued to grow year by year. Object in this study is focused on development plan of standard water reservoir Kacang Butor Village, Badau District, Belitung Regency, Bangka Belitung Islands Province. Development plan for standard water reservoir facility didn't proceed as well as planned because there was no agreement between government and landowners regarding the value of compensation. Public Work Service as the executor of land acquisition use Tax Object Sales Value to determine exact amount of compensation for land acquisition. Compensation calculation based on Tax Object Sales Value id rejected by landowners because it is not in accordance with landowner expectations.

This study tries to determine the exact amount of compensation that can be accepted by landowner whose land is acquired by using Fair Replacement Value. This study is important to conduct because obstacles that driven by discrepancy of expectation for compensation between government and landowners can be detrimental for area where construction of facilities for public interest take place. Alemu (2013) also assert that the purpose of development for public interest is to ascertain safety and security, health and welfare, social and economic enhancement, and protection and restoration of natural environment. Inhibition of development for the public interest due to disagreement for land acquisition compensation from the government can cause delays in improving aspects of community life.

\section{METHODS OF RESEARCH}

This research is conducted in Kacang Butor Village, Badau District, Belitung Regency, Indonesia, especially in land acquisition location that will be built standard water reservoir. Area that will be used as standard water reservoir consists of 27 land plots that have breadth 
approximately $152,323 \mathrm{~m}^{2}$. This research uses case study method to elucidate descriptively about phenomenon that occurred, namely landowners refusal whose land will be used to develop standard water reservoir in Kacang Butor Village due to discrepancy of the compensation value given by government. There are two types of data used in this research, namely:

Primary data derived from interview results with some key informants who are relevant parties involved in execution of land acquisition in Kacang Butor Village, namely:

- Mr. A husband of landowner.

- Mr. D external appraiser from Public Appraiser Office.

- Mr. R from Kantor Public Work Service Office.

- Mrs. S from National Land Agency Office/Ministry of Agrarian and Spatial Planning of Belitung Regency.

Secondary data acquired with documentation technique on some documents obtained from relevant agencies with research object, such as National Land Agency Office/Ministry of Agrarian and Spatial Planning of Belitung Regency, Public Work Office, Plantation Service, and from local urban village office. Secondary data required in this study inter alia:

- Regulations regarding fair replacement value of land acquisition for development for public interest.

- Data of RT and RW of Belitung Regency.

- Market data for buildings, businesses and plants.

Researcher then determines compensation calculation technique that will be used to determine exact amount of compensation that will be given to landowners whose land will be acquired. In contrast with government who too simplify the amount of compensation determination using Tax Object Sales Value which eventually lead to landowners refusal. Government doesn't have clear standards or guidelines for asset valuation like United Kingdom (Andrew and Pitt, 2000; Andrew and Pitt, 2004; Connellan, 1997; Dent, 1997) which lead to compensation determination for land acquisition that to simplicistic. Researcher therefore determines the exact amount of compensation or Fair Replacement Value by taking into account physical loss and non-physical loss. There are two reasons why this calculation technique is chosen, namely (1) calculation technique using fixed rates such as those performed by Public Work Service is more susceptible to landowners refusal (Yuan, 1990), and (2) this compensation determination technique is accordance with compensation determination technique in Australia and is proven more acceptable for landowner whose land will be acquired (Newell et al., 2011).

Data analysis technique in this research is divided into several phases, namely:

The first phase refers to Noor et al. (2013), which is to analyze archived data obtained to determine the exact amount of Fair Replacement Value of land acquisition.

Researcher divides land area that will be appraised based on land potential into three type of land, i.e. highway roadside land, village roadside land, and inland ground.

Research determines Fair Replacement Value by calculating physical loss value using market approach and non-physical loss value that consists of premium (solatium and cost of moving and discharging), cost of transaction (Income Tax and cost of Land Deed Official), waiting period interest and other losses.

Researcher then conduct an interview with key informants to ask comparison between compensation that based on Tax Object Sales Value and Fair Replacement Value to conclude whether Fair Replacement Value is more acceptable by landowners or not.

\section{RESULTS AND DISCUSSION}

Object in this research is 27 land plots that will be acquired and used as standard water reservoir with breadth approximately $152,683 \mathrm{~m}^{2}$. Important places/buildings that can become a guidance where the object of assessment is HAS Hanandjudin Airport, Kacang Butor Village Office, Kacang Butor Primary School, Tajam Mountain. 


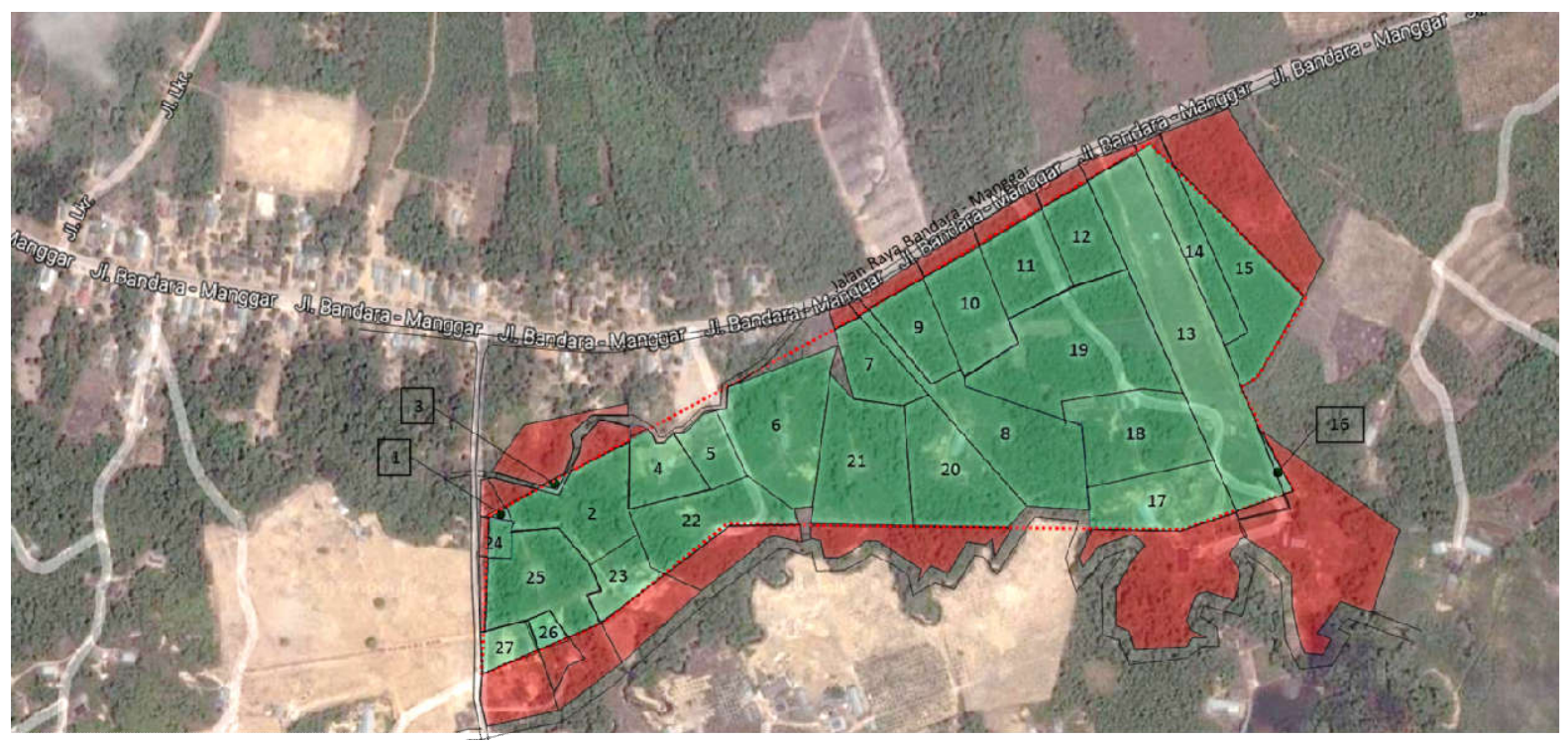

Figure 1 - Land Condition Without Scale

Determination of boundary is conducted by making a map about land zoning based on proof of land ownership rights. Data collected are 27 proofs of land ownership rights. Proof that has been collected is proof of ownership other than certificate. Every proof is not a certificate of ownership, but still in the form of Land Certificate and Deed of Relinquishment of Rights on Land. Researcher also conducted observations and interviews with local village apparatus. It aims to obtain data regarding land sale and purchase transations that occurred in area of research object i.e. Kacang Butor Village from 2010 to 2016 . This data is then used as comparative data (market comparison) on land that will be acquired.

There are 9 comparative data used to analyze that meet physical characteristics, have similiarities and are located close to appraisal object. It is expected that with similiarity and location that adjacent with the object then adjustment in method of market data approach is not significant. Researcher then divides 27 land plots which are an appraisal object into 3 groups of land appraisal objects based on type and distance of appraisal object or zoning location. It is done to facilitate data analysis in determining market value, so in analysis of market value determination as physical loss there are three market values of land per square meter. The three land parcels consist of highway roadside land, village roadside land, and inland ground.

Highway Roadside Land. Highway roadside land is a land parcels located in roadside of Airport - Manggar highway in Kacang Butor Village.

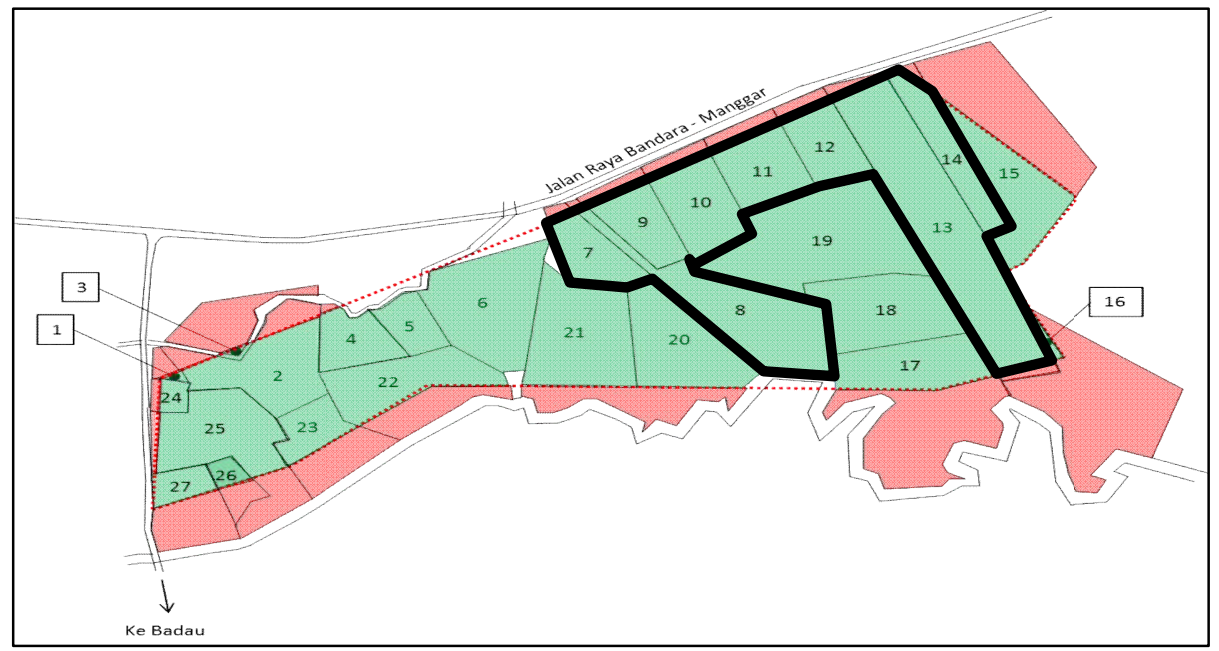

Figure 2 - Highway Roadside Land 
Researcher argues that land plot located in roadside of highway has the highest market value compared with other land plots. It is due to ease of access to the highway and it is directly tangent to the highway.

Table 1 - Comparative Data of Highway Roadside Land

\begin{tabular}{|c|c|c|c|c|c|c|}
\hline No. & Owner of Land & Land Type & Width $\left(\mathrm{m}^{2}\right)$ & Bid Price & Land Price $\left(\mathrm{m}^{2}\right)$ & Proof of Ownership \\
\hline 1 & Yuda & Roadside & 7,500 & $250,000,000 .-$ & 33,300 & SKT \\
\hline 2 & Marli & Roadside & 7,240 & $300,000,000 .-$ & 41,400 & SKT \\
\hline 3 & Kokoy & Roadside & 8,000 & $240,000,000 .-$ & 30,000 & SKT \\
\hline
\end{tabular}

Village Roadside Land. Village roadside land is a land parcels located adjacent with village roadside. This group of lands is not directly adjacent with Airport - Manggar highway but located side by side with village road leading to Badau. Therefore, researcher deduces that land market value in this group called village roadside land is smaller or lower compared with market value of highway roadside land.

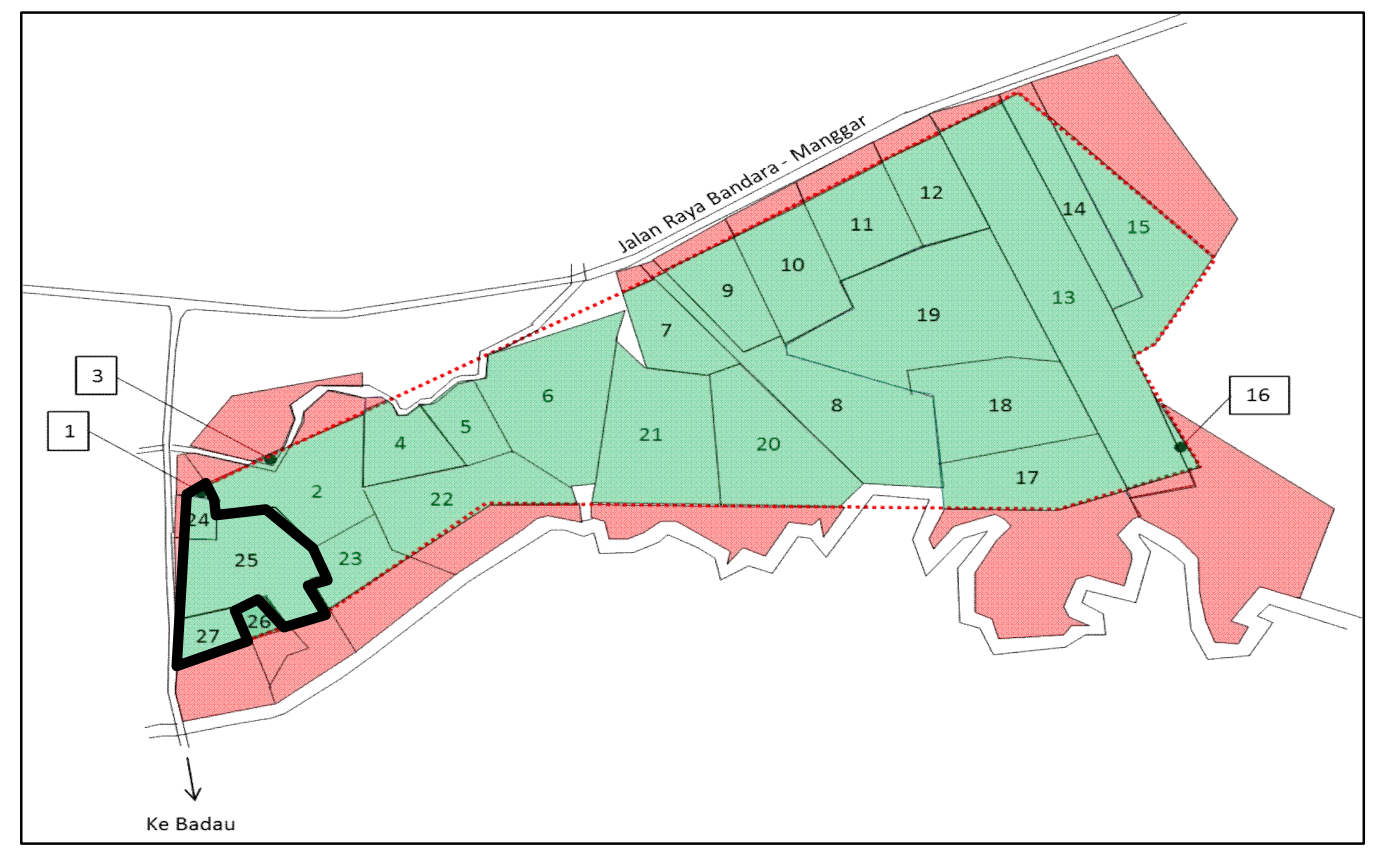

Figure 3 - Village Roadside Land

Table 2 - Comparative Data of Village Roadside Land

\begin{tabular}{|c|c|c|c|c|c|c|}
\hline No. & Owner of Land & Land Type & Width $\left(\mathrm{m}^{2}\right)$ & Bid Price & Land Price $\left(\mathrm{m}^{2}\right)$ & Proof of Ownership \\
\hline 1 & Yuda & Roadside & 7,500 & $250,000,000 .-$ & 33,300 & SKT \\
\hline 2 & Marli & Roadside & 7,240 & $300,000,000 .-$ & 41,400 & SKT \\
\hline 3 & Kokoy & Roadside & 8,000 & $240,000,000 .-$ & 30,000 & SKT \\
\hline
\end{tabular}

Inland Ground. Inland ground is a land located deeper than highway roadside land and village roadside land. According to researcher observations, this group called inland ground has the lowest market value compared with highway roadside land and village roadside land. It is due to inland ground location that makes this group of land unfavorable.

Table 3 - Comparative Data of Inland Ground

\begin{tabular}{|l|l|l|l|l|l|l|}
\hline No. & Owner of Land & Land Type & Width $\left(\mathrm{m}^{2}\right)$ & Bid Price & Land Price $\left(\mathrm{m}^{2}\right)$ & Proof of Ownership \\
\hline 1 & Masri & Inland & 8,000 & $72,000,000 .-$ & 9,000 & SKT \\
\hline 2 & Yuli & Inland & 5,000 & $60,000,000 .-$ & 12,000 & SKT \\
\hline 3 & Budi & Inland & 7,000 & $60,000,000 .-$ & 8,500 & SKT \\
\hline
\end{tabular}




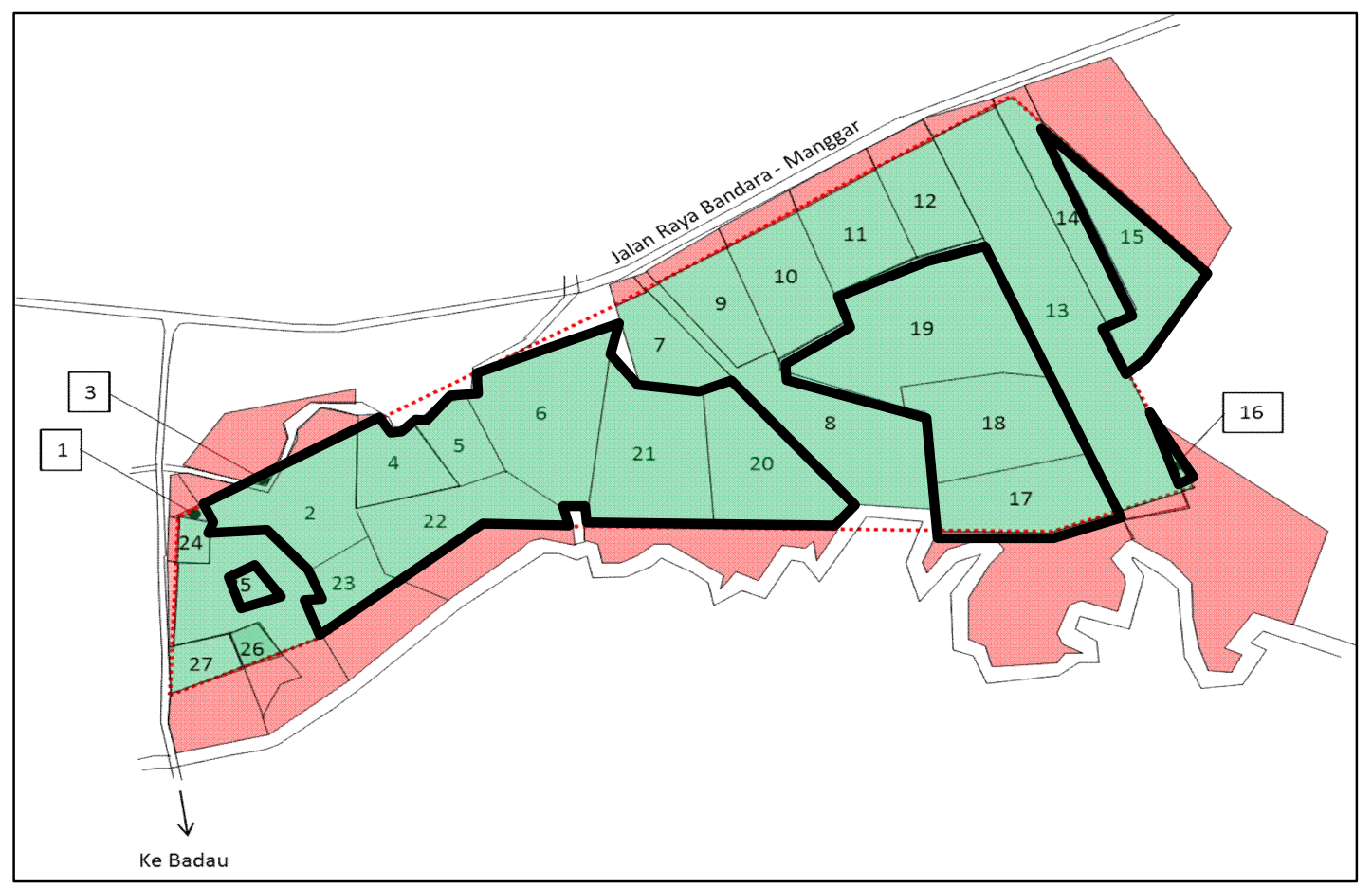

Figure 4 - Inland Ground

Fair Replacement Value Analysis. Fair Replacement Value in this research is a sum of physical loss that generated from land market value and non-physical loss that generated from Land and Building Title Transfer Duty (BPHTB), cost of Land Deed Official (PPAT) and waiting period interest. Table 4 presents value of physical loss and non-physical loss, while Table 5 exhibits calculation of Fair Replacement Value.

Table 4 - Value of Physical Loss and Non-Physical Loss

\begin{tabular}{|c|c|c|c|c|c|}
\hline No. & Physical Loss & BPHTB (5\%) & PPAT (1,5\%) & INTEREST (2\%) & Non-Physical Loss \\
\hline \multicolumn{7}{|c|}{ HIGHWAY ROADSIDE LAND } \\
\hline 1 & $1,643,648,800 .-$ & $82,180,000 .-$ & 24,650,000.- & 32,870,000.- & $139,700,000 .-$ \\
\hline \multicolumn{7}{|c|}{ VILLAGE ROADSIDE LAND } \\
\hline 2 & $208,853,700 .-$ & $10,440,000 .-$ & $3,130,000 .-$ & $4,180,000 .-$ & $17,750,000 .-$ \\
\hline 3 & 775.848 .600 & $38,770,000 .-$ & $11,630,000 .-$ & $15,510,000 .-$ & 65.910 .000 \\
\hline Total & 2.628 .351 .100 & $131,390,000 .-$ & $39,410,000 .-$ & $52,560,000 .-$ & 223.360 .000 \\
\hline
\end{tabular}

Table 5 - Calculation of Fair Replacement Value

\begin{tabular}{|c|c|c|c|c|}
\hline No. & Land Zoning & Physical Loss & Non-Physical Loss & Fair Replacement Value \\
\hline 1 & Highway Roadside Land & 1,643,648,800.- & 139,700,000.- & 1,783,348,800.- \\
\hline 2 & Village Roadside Land & 208,853,700.- & $17,750,000 .-$ & $226,603,700 .-$ \\
\hline 3 & Inland Ground & 775,848,600.- & 65,910,000.- & 841,758,600.- \\
\hline & Total & 2,628,351,100.- & $223,360,000 .-$ & 2,851,711,100.- \\
\hline
\end{tabular}

According to Table 4 and 5, it can be concluded that Fair Replacement Value which consists of physical loss and non-physical loss components exhibit that value generated above actual market value of land sold directly or not through land acquisition mechanism. Researcher gets some evidence from interview conducted with several key informants. Firstly, through interview with landowners it is known that some landowners questioned the difference in basic calculation of land per square meter. After socialization regarding why there is a difference in calculation of land base with Public Appraiser Office, landowners have better understanding about how the difference occur and receive fair replacement value that has been determined. 


\section{CONCLUSION}

This study is conducted due to a dispute regarding compensation value of land acquisition for public interest. Government previously used Tax Object Sales Value as a basis for calculating compensation for land acquisition that considered less appropriate for determining compensation value for landowners whose land is acquired for development of infrastructure and facilities. The existence of non-physical loss calculation provides value added for land that will be acquired, so that the final value for compensation becomes greater or equal with market value, and if the value is above or at least equal with market value, then it is certain that the value that generated with calculation conducted by external appraiser is higher than Tax Object Sales Value. Interpretation of Table 4 and Table 5 along with interview result shows that replacement value provided from fair replacement value mechanism accommodate landowners expectation for amount of compensation they will receive.

Nevertheless there are some aspect that can't be fully accommodated through calculation of Fair Replacement Value by summing physical loss and non-physical loss value. In line with statement from Adair and Hutchison (2005) that explicate about inherent risk which in appraisal process of an assets, so there is no appraisal process that can be conducted flawlessly and satisfy all related. Researcher refer to Adam (2015) also gives some suggestion to government that financial compensation is not the only way to compensate landowners whose land is acquired for facilities development for public interest. Government may also consider land readjustment as an alternative of indemnification.

\section{REFERENCES}

1. Adair, A., \& Hutchison, N. (2005). The Reporting Of Risk In Real Estate Appraisal Property Risk Scoring. Journal of Property Investment \& Finance 23(3), 254-268.

2. Adam, A. G. (2015). Land Readjustment as an Alternative Land Development Tool For Peri-Urban Areas Of Ethiopia. Property Management 33(1), 36-58.

3. Adler, R., Stringer, C., \& Yap, M. (2016). The Valuation and Pricing of Information Assets. Pacific Accounting Review 28(4).

4. Alemu, B. Y. (2013). Expropriation, Valuation And Compensation Practice In Ethiopia: The Case Of Bahir Dar City And Surrounding. Property Management 31(2), 132-158.

5. Andrew, A., \& Pitt, M. (2000). Asset Valuation Of Specialised Public Sector Listed Buildings By Depreciated Replacement Cost. Journal of Property Investment \& Finance 18(6), 627-636.

6. 2004. Property Appraisal In Government. Journal of Property Investment \& Finance 22(2), 192-199.

7. Babatunde, S. O., Adeniyi, O., \& Awodele, O. A. (2017). Investigation Into The Causes Of Delay In Land Acquisition For PPP Projects In Developing Countries. Journal of Engineering, Design and Technology.

8. Connellan, O. (1997). Valuation Of Specialized Public Sector Assets. Property Management 15(4), 215-225.

9. Dent, P. (1997). Managing Public Sector Property Assets: The Valuation Issues. Property Management 15(4), 226-233.

10. Dickinson, P. G. (2010). Foreign SMEs And Land Acquisition The Reality Of Regulation (The Case Of Estonia). Journal of International Trade Law and Policy 9(1), 83-96.

11. Fratmawati, D. (2006). Pengadaan Tanah Bagi Pelaksanaan Pembangunan Untuk Kepentingan Umum Di Semarang (Studi Kasus Pelebaran Jalan Raya Ngaliyan-Mijen). Tesis Program Magister Kenotariatan, Universitas Diponegoro, Semarang.

12. Mangioni, V. (2010). The Evolution Of The "Public Purpose Rule" In Compulsory Acquisition. Property Management 28(2), 93-103.

13. Muller III, K. A., \& Riedl, E. J. (2002). External Monitoring Of Property Appraisal Estimates and Information Asymmetry. Journal of Accounting Research 40(3), 865-881. 
14. Mulyanti, R. (2013). Analisis Pengadaan Tanah Untuk Kepentingan Umum (Studi Kasus Pembangunan Jalan Tol Jorr West 2). Tesis Program Magister Konatariatan, Universitas Indonesia, Indonesia.

15. Newell, G., Chan, N., \& Goodridge, E. (2011). Risk Assessment And Compensation Analysis Of Court Decisions In Compulsory Land Acquisition Compensation Cases In Australia. Journal of Property Investment \& Finance 29(2), 210-219.

16. Noor, M. A., Khalfan, M. M. A., \& Maqsood, T. (2013). The Role Of Procurement Practices In Effective Implementation Of Infrastructure Projects In Pakistan. International Journal of Managing Projects in Business 6(4), 802-826.

17. Odudu, C. O. (2017). Compensation Study of Boboroku, Jesse, Delta State, Nigeria. Property Management.

18. Ogedengbe, P. S. (2007). Compulsory Acquisition Of Oil Exploration Fields In Delta State, Nigeria. Journal of Property Investment \& Finance 25(1), 62-76.

19. Omar, I., \& Ismail, M. (2009). Kotaka's Model in Land Acquisition for Infrastructure Provision in Malaysia. Journal of Financial Management of Property and Construction 14(3), 194-207.

20. Opawole, A., \& Jagboro, G. O. (2016a). Benchmarking Parties' Obligations In The Execution Of Concession-Based PPP Projects In Nigeria. Journal of Place Management and Development 9(1), 27-46.

21. 2016. Factors Influencing the Scope of Private Party's Obligations In Concession-Based PPP Projects In Nigeria. Structural Survey 34(3), 297-314.

22. Republik Indonesia. 1975. Peraturan Dalam Negeri (Permendagri) No. 15 Tahun 1975 tentang Ketentuan-Ketentuan Mengenai Tata Cara Pembebasan Tanah. Lembaran Negara RI Tahun 1975. Sekretariat Negara. Jakarta.

23. 1993. Keputusan Presiden No. 55 Tahun 1993 tentang Pengadaan Tanah Bagi Pelaksanaan Pembangunan untuk Kepentingan Umum. Lembaran Negara RI Tahun 1993. Sekretariat Negara. Jakarta.

24. 2006. Peraturan Presiden No. 65 Tahun 2006 tentang Pengadaan Tanah bagi Pembangunan untuk Kepentingan Umum. Lembaran Negara RI Tahun 2006. Sekretariat Negara. Jakarta.

25. 2012. Undang-Undang No. 2 Tahun 2012 tentang Pengadaan Tanah bagi Pembangunan untuk Kepentingan Umum. Lembaran Negara RI Tahun 2012. Sekretariat Negara. Jakarta.

26. Yuan, L. L. (1990). Public Sector Valuations. Journal of Valuation 8(2), 166-183. 